\title{
“SEMAMPAI” SEHAT, MANAJERIAL, MANDIRI, DAN PANDAI: KKN-PPM, MUARA ANCALONG, KUTAI TIMUR
}

\author{
Rudy Agung Nugroho', Ari Susandy Sanjaya², Iwan Muhammad Ramdan³, \\ Rudianto $^{1}$, Widha Prahastika ${ }^{1}$ \\ 1Laboratorium Fisiologi, Perkembangan dan Molekuler Hewan, Jurusan Biologi Fakultas MIPA \\ Universitas Mulawarman, Samarinda, Kalimantan Timur \\ 2Fakultas Teknik, Universitas Mulawarman, Samarinda, Kalimantan Timur \\ 3Fakultas Kesehatan Masyarakat Universitas Mulawarman, Samarinda, Kalimantan Timur \\ rudyagung.nugroho@fmipa.unmul.ac.id
}

\begin{abstract}
Community Development Program-learning and community service program or Kuliah kerja nyatapembelajaran dan pengabdian kepada masyarakat (KKN-PPM) which is a form of community service has been done from July-August 2019 in the Kelinjau Ulu and Kelinjau Ilir village, Muara Ancalong, East Kutai, East Kalimantan. The purpose of the KKN-PPM was to empower the community to be more productive. The KKN-PPM program's theme was "Semampai," which means healthy, managerial, independent, and intelligent. Twenty undergraduate students performed the KKN-PPM from various faculties and under supervision by field supervisors. In addition to these thematic activities and the KKNPPM program, each undergraduate student also performed individual programs related to their scientific background. In conclusion, the KKN-PPM helps Kelinjau Ulu and Ilir enhance productivity, be healthier, actively reading and more intelligent, and more insightful.
\end{abstract}

Keywords: Community empowerment, Kelinjau Ulu dan Ilir, Kutai Timur, semampai

\begin{abstract}
Abstrak
Telah dilaksanakan program kuliah kerja nyata-pembelajaran dan pengabdian kepada masyarakat (KKNPPM) pada bulan Juli-August 2019 di desa Kelinjau Ulu dan Kelinjau Ilir, Muara Ancalong, Kutai Timur, Kalimantan Timur. Tujuan KKN-PPM adalah memberdayakan masyarakat kedua desa agar lebih produktif. Kegiatan KKN-PPM ini mengambil tema "semampai": sehat, manajerial, mandiri dan pandai. Bersama kegiatan ini, masyarakat desa dapat mempunyai hidup lebih sehat dengan cara manajemen sampah, mandiri dengan hidroponik dan pengasapan ikan, serta peningkatan minat baca generasi muda melalui perpustakaan baca, agar makin pandai. Kegiatan dilaksanakan oleh 20 mahasiswa dari berbagai fakultas dan diawasi 3 dosen pendamping lapangan. Selain kegiatan tematik tersebut, tiap mahasiswa juga menjalankan program individu yang terkait bidang keilmuan. Program KKN-PPM dilakukan dengan metode penyuluhan, praktek pengelolaan sampah, pembuatan hidroponik, mesin pengasap, pengelolaan perpustakaan dan pengajaran. Dengan KKN-PPM ini, produktivitas masyarakat kedua akan makin meningkat, sehat, mempunyai kemandirian pangan dan generasi muda yang giat membaca serta makin pandai dan berwawasan.
\end{abstract}

Kata kunci: Pemberdayaan Masyarakat, Kelinjau Ulu dan ilir, Kutai Timur, Semampai 


\section{PENDAHULUAN}

\section{Analisis situasi}

Kecamatan Muara Ancalong mempunyai luas daerah berkisar 2.234,17 km2 serta jumlah penduduk 3.968 Kepala keluarga, sekitar 15.214 jiwa. Suku atau etnis yang ada di Muara Ancalong yaitu suku Bugis, Jawa, Kutai, Dayak, Banjar dan Melayu. Ditinjau dari sisi geografis, Wilayah kecamatan Muara Ancalong terletak di Kabupaten Kutai Timur (0-2o Lintang Utara; 116 - 1180 Bujur Timur). Daerah ini mempunyai ketinggian 200250 meter di atas permukaan air laut. Wilayah kecamatan Muara Ancalong mempunyai batas wilayah sebagai berikut:

Kecamatan Muara Bengkal di bagian Timur, Kecamatan Muara Wahau di bagian Utara, Kecamatan Busang (Kabupaten Kutai Timur) dan Kecamatan Kembang Janggut (Kabupaten Kutai Kartanegara).

di bagian barat, dan Kecamatan

Muara Kaman (Kabupaten Kutai Kartanegara) di sebelah Selatan dengan Kecamatan Muara Kaman (Kabupaten Kutai Kartanegara).

Ada 8 desa di wilayah Kecamatan Muara Ancalong yakni Desa: Kelinjau Ilir, Kelinjau Ulu, Senyiur, Long Nah, Long Poq Baru, Gemar Baru, Muara Dun, dan Long Tesak.

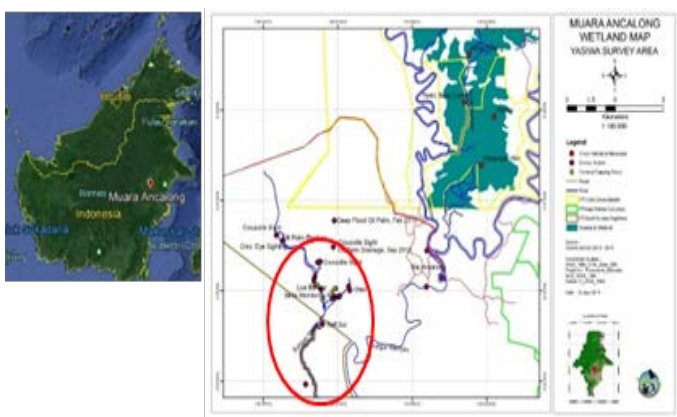

Gambar 1. Peta lokasi Muara Ancalong Kutai timur. Jarak lokasi mitra dengan perguruan tinggi
Sumber utama penghasilan penduduk Muara Ancalong yaitu buruh, serta nelayan. Oleh karena itu, sebagai nelayan sangat bergantung pada alam dan sumberdayanya. Wilayah Muara Ancalong mempunyai potensi yang tinggi di bidang perikanan air tawar. Oleh karenanya, penduduk Desa Kelinjau Ulu dan ilir mempunyai ketergantungan terhadap kondisi alam dan musim. Secara umum kondisi produksi ikan hasil tangkapan yang ada di Indonesia terus mengalami kenaikan dan menghasilkan angka di kisaran 7 juta ton pada akhir 2015 (Duta, 2015). Di sisi lain wilayah Kalimantan Timur, hasil ikan ada pada kisaran 154.439-ton di tahun 2016 (Ghofar, 2016). Dari penelitian dan pengamatan yang telah diterbitkan, di sekitar desa kelinjau ulu dan ilir yaitu di wilayah Sungai Suwi, Kecamatan Muara Ancalong ditemukan ada sebelas famili serta tujuh ordo ikan di penghujung tahun 2015 (Nugroho et al., 2016). Beberapa di antara ikan tangkap tersebut adalah jenis yang sering dikonsumsi, yaitu ikan belida patin, haruan, papuyu, baung serta lais.

Ikan tangkap tersebut di atas kemudian diproses dengan pengeringan oleh nelayan. Proses pengeringan mengandalkan sinar matahari dan penggaraman. Setelah beberapa hari dan kering, ikan dapat segera dijual atau disimpan. Kondisi ketergantungan pada sinar matahari secara alamiah membuat ikan terkadang menjadi busuk karena proses pengeringan yang kurang kering dan tumbuhnya mikrobia pembusuk. Dampaknya adalah nilai jual yang turun, serta cita rasa ikan yang berkurang. Hal tersebut menyebabkan kerugian bagi nelayan setempat. Selain Permasalahan di atas, masyarakat di desa tersebut masih membuang sampah di sungai; Minat membaca anak-anak usia sekolah masih rendah dan kurang ada fasilitas baca. Hanya mengandalkan 
Rudy Agung Nugroho, dkk. “Semampai” Sehat, Manajerial, Mandiri, Dan Pandai...

perekonomian utama dari sektor Perikanan, Sementara tidak ada sektor pendukung.

Saat ini Desa Kelinjau ulu dan ilir telah menjalin kerjasama dengan Yayasan ulin. Yayasan tersebut bergerak di bidang sosial kemasyarakatan serta penanganan Konservasi. Yayasan ulin telah ada kerjasama yang baik dalam masalah pengelolaan lingkungan, namun belum ada program yang terintegrasi dan kerjasama dengan perguruan tinggi. Berdasarkan hasil riset dan kajian awal di kedua desa tersebut, masalah sampah masih menjadi hal utama yang harus dibenahi. Sebagian masyarakat masih membuang sampah ke sungai, tidak adanya pengelolaan sampah yang baik. Mata pencaharian sebagai nelayan merupakan mata pencaharian pokok, sehingga jika hasil tangkap menurun maka, pemasukan secara ekonomi juga menurun. Sebaliknya jika stok ikan sedang melimpah, penanganan ikan hasil tangkapan yaitu pengeringan hanya mengandalkan sinar matahari dan kondisinya kurang higienis.

Di samping itu di sektor pendidikan, minat baca generasi muda sangatlah rendah. Untuk itulah, kegiatan Kuliah kerja nyata-pembelajaran dan pemberdayaan masyarakat ini dibuat untuk dapat memberikan solusi permasalahan di kedua desa. Bersamasama dengan masyarakat (Working with community), perguruan tinggi secara aktif akan bermitra dengan masyarakat dan mitra Yayasan ulin memberikan pembelajaran dan pemberdayaan dalam upaya menjadikan lingkungan kedua desa menjadi sehat, dapat mengolah sampah sehingga lingkungan bersih, dapat mandiri dan mempunyai ketahanan pangan dengan adanya hidroponik dan pengasapan ikan serta mendorong generasi muda untuk lebih berminat membaca dengan adanya perpustakaan.

\section{Permasalahan Mitra}

Kondisi di kedua desa yaitu kelinjau ilir dan ulu masyarakatnya masih sering membuang sampah di sungai, hal ini membuat sungai menjadi kotor dan lingkungan perairan menjadi tidak sehat. Permasalahan berikutnya adalah ketergantungan terhadap hasil tangkapan ikan bagi nelayan. ketika hasil tangkapan banyak, maka pengolahan pasca tangkap ikan kurang higienis, karena hanya dijemur di bawah terik matahari dan banyak lalat. Pada saat tangkapan sedikit, maka tidak ada hasil lain yang digunakan untuk mencukupi kebutuhan ekonomi. sementara itu, bagi generasi muda, minat baca sangat rendah.

Program KKN-PPM ini mencoba memberikan pembelajaran dan pemberdayaan masyarakat dengan cara, pembekalan, pembelajaran, dan pemberdayaan secara soft skill kepada masyarakat Muara Ancalong yang ada di desa Kelinjau Ulu dan Ilir untuk dapat menerapkan teknik manajemen dan pengolahan sampah, pembuatan kompos, hidroponik, pengasapan ikan dan peningkatan minat baca.

\section{Solusi permasalahan}

Permasalahan: 1) masyarakat masih membuang sampah di sungai; 2) banyak penduduk yang mengandalkan perikanan tangkap sungai, sedangkan kadang hasil tangkapan menurun pada masa-masa tertentu; 3) Hasil ikan tangkapan dikeringkan dan diolah mengandalkan sinar matahari dan kurang higienis, karena dikerubungi lalat, nilai nutrisi turun dan minat masyarakat rendah, nilai jual rendah; 4) Minat membaca anak-anak usia sekolah masih rendah dan kurang ada fasilitas baca. Solusi yang ditawarkan adalah 1) 
Manajemen pengelolaan sampah di lokasi KKN 2) Pembuatan percontohan hidroponik untuk mengatasi permasalahan turunnya hasil tangkapan ikan 3) Penerapan mesin pengasap sederhana untuk pengolahan ikan pasca tangkap; 4) pembuatan perpustakaan mini dan sosialisasi pentingnya membaca bagi generasi pelajar (SD) serta penerapan tutor sebaya.

Kontribusi kegiatan pada khalayak masyarakat adalah, 1) memberikan pembelajaran dan pemberdayaan masyarakat mengenai manajemen pengelolaan sampah dan pemanfaatannya agar lingkungan desa lebih bersih, rapi dan higienis serta sehat. 2) Teknologi tepat guna dalam menggunakan mesin pengasap ikan yang bermanfaat langsung bagi masyarakat nelayan di desa kelinjau. nilai harga jual ikan pasca tangkap meningkat, nilai gizi dapat dipertahankan, minat beli masyarakat terhadap ikan asap naik dan meningkatkan nilai perekonomian kerakyatan di wilayah tersebut 3) Pemberdayaan dan peningkatan perekonomian dengan usaha hidroponik sebagai sampingan dari kegiatan nelayan dan buruh. 4) Peningkatan minat baca dan belajar bagi generasi muda dan edukasi bagi masyarakat secara umum akan pentingnya peningkatan pendidikan dengan membaca dengan adanya perpustakaan mini.

\section{METODE}

\section{Garis besar pelaksanaan}

Untuk menjawab permasalahan yang ada di daerah pengabdian kegiatan, KKN-PPM adalah salah satu solusi untuk membantu menjawab masalah yang muncul. program yang dilaksanakan adalah: sosialisasi manajemen sampah, pembuatan beberapa tempat sampah yang terpisah antara organik dan non organik, pembuatan tempat pembuatan kompos, hidroponik, pengasapan ikan, dan perpustakaan mini. Secara umum program KKN PPM ini dilakukan dalam 2 cara yaitu pendampingan/penyuluhan (teori) dan prakteknya adalah berupa pembimbingan secara langsung. Pelaksanaan program dilakukan selama 50 hari efektif. Sejumlah 20 mahasiswa dari berbagai fakultas ditempatkan di desa Kelinjau ulu dan di desa kelinjau ilir. Masing-masing dibagi menjadi kelompokan mahasiswa akan melakukan kegiatan-kegiatan sebagai berikut:

\section{Penyuluhan berupa teori}

Tim mahasiswa KKN PPM telah memberikan penyuluhan teori tentang manajemen sampah, pengasapan ikan, hidroponik, dan dunia pendidikan. Dalam pendampingan ini disampaikan aspek yang menyangkut tentang budidaya ikan dan pembuatan kompos. Di dalam teori ini, masing-masing kelompok masyarakat dari tiap desa dikumpulkan dalam satu acara serta tempat di Muara Ancalong dan diberikan penyuluhan serta penjelasan mengenai gambaran KKN PPM. Cara penyampaian penyuluhan yaitu presentasi, kemudian dilanjutkan dengan diskusi serta tanya jawab.

\section{Sesi praktek}

Tim mahasiswa KKN PPM memberikan transfer soft skill serta pendampingan langsung kelompok masyarakat mengenai teknik pengolahan sampah, pembuatan kompos, hidroponik, pengasapan ikan hingga penggunaannya, dan teknik mengelola perpustakaan. Di sesi akhir praktek dan tiap kegiatan dilakukan evaluasi keberhasilan program. 
Rudy Agung Nugroho, dkk. "Semampai” Sehat, Manajerial, Mandiri, Dan Pandai...

\section{Tata laksana program}

Dalam pelaksanaan program KKN PPM ini, tim KKN PPM membuat pendataan kembali anggota kelompokkelompok masyarakat yang turut serta dalam kegiatan pembelajaran, praktek pembimbingan, serta kegiatan program pendampingan KKN PPM. Di lain hal mitra yayasan ulin, membantu dalam persiapan tempat berlangsungnya acara, pertemuan serta pendampingan pertama (Teori) dan pertemuan dan pendampingan selanjutnya (Praktek). Selain itu, mitra yayasan ulin juga mempersiapkan tempat untuk keperluan praktek, pendirian tenda untuk kegiatan praktek pengolahan sampah dan pembuatan kompos

Langkah awal dalam pengelolaan dan manajemen sampah adalah: Pengumpulan Sampah; Pemisahan Sampah berdasarkan jenis dan keperluannya; mengkomposting (Bokasi) sampah organik menjadi pupuk. Kemudian langkah yang harus ditempuh adalah adanya Tempat Pembuangan Sementara (TPS). Hal-hal yang dapat diuraikan adalah: Lokasi yang dapat digunakan; Luas daerah yang tersedia; Jumlah (volume) sampah yang akan dibuang; Peralatan yang dibutuhkan; Biaya; dan dampak lingkungan dari penimbunan sampah.

Tahapan pengelolaan adalah: koleksi atau Pengumpulan, pengangkutan dan pembuangan. Saat ini, sampah yang telah dipisahkan antara sampah organik dan non organik, dapat dimanfaatkan menjadi pupuk terutama dari sampah organik, yaitu dibuat pupuk kompos.

\section{Metode pengasapan ikan}

Pengasapan ikan adalah salah satu metode pengawetan ikan. Teknik pengawetan ikan ini menggunakan asap sebagai cara untuk mengawetkan ikan (Prasetyo et al., 2015). Teknik pengawetan ikan dengan menggunakan asap juga merupakan cara alternatif dalam strategi penanganan ikan pasca tangkap dari alam yang tidak memungkinkan untuk segera dijual di pasaran atau masyarakat, Ikan yang diasap juga bermanfaat bagi ikan yang tidak segera dikonsumsi atau jika jumlah ikan yang ditangkap sangat melimpah. Ikan yang diasap ini selain menjadi lebih awet tidak cepat busuk, kualitas mutu dapat terjaga serta memunculkan kelezatan baru bagi konsumennya (Ibrahim, 2014).

Cara pengasapan ikan sebagai upaya pengawetan ini, mempunyai banyak keunggulan di samping sebagai upaya pengawetan ikan juga memunculkan rasa serta warna pada ikan yang khas dan menarik minat konsumen. Hal ini terutama bagi penikmat ikan yang hobi dengan cita rasa ikan asap, selain lezat dari sisi keamanan pangan ikan asap tetap terjaga dan masih dalam standar aman untuk dimakan (Swastawati et al., 2017).

Pada dasarnya, pengasapan ikan menggunakan asap yang bersumber dari material kering yang di bakar. Material kering tersebut yaitu briket, kayu, atau material yang mudah terbakar (Samuel et al., 2015). Asap yang timbul dari proses pembakaran tersebut yaitu uap serta partikel padatan dengan ukuran mikro. Sebagai tambahan, uap yang 
dihasilkan dari hasil pembakaran ikan asap mempunyai komposisi berupa air, asam asetat, aldehid, asam formiat, fenol, keton, alkohol, serta karbohidrat (Royani et al., 2014). Asap yang dihasilkan mempunyai fungsi pengawetan, karena dapat membunuh bakteri yang dapat membusukan dan merusak ikan. Di samping itu ikan yang telah diasap, akan bertambah awet dengan mencegah adanya proses oksidasi lemak pada ikan. Proses pengasapan menimbulkan warna pada daging ikan menjadi kuning kecoklatan (Widiyanto et al., 2015).

Secara umum, proses pengasapan ikan adalah kombinasi proses penggaraman, pengeringan, dan pemanasan serta pengasapan. Dalam penggaraman, dilakukan sebagai bentuk pengawetan ikan. Sementara itu, kadar garam dan waktu penggaraman dapat dilakukan sesuai selera, besar kecil ikan, jenis ikan yang diasap, dan tingkat kesegaran ikan tangkap. Pemberian garam dimaksudkan agar tekstur daging ikan menjadi kompak. Selain itu, bakteri pembusuk pertumbuhannya dapat ditekan dan dihambat. Penggaraman juga memunculkan rasa daging lebih enak. Proses pengeringan bermanfaat, agar proses pengasapan lebih baik dan juga mengurangi kadar air. Proses pengeringan juga bertujuan agar asap dapat kembali masuk kedalam daging, sehingga teksturnya menjadi lebih baik. Proses pemanasan dengan suhu tinggi juga bertujuan menghentikan aktivitas enzim yang dapat merusak daging ikan. Pemanasan juga menggumpalkan protein dan mengurangi kadar air yang masih ada di dalam daging. Adapun lama pengasapan, tingkat suhu, dan banyaknya volume asap akan berpengaruh terhadap kualitas daging ikan asap yang dihasilkan (Jeujanan et al., 2015).

\section{Hidroponik}

Semakin langkanya lahan pertanian akibat dari banyaknya sektor industri dan jasa, membuat kegiatan usaha pertanian konvensial semakin tidak kompetitif karena tingginya harga lahan. Sistem hidroponik dapat dijadikan alternatif bagi masyarakat yang mempunyai lahan terbatas atau pekarangan, sehingga dapat dijadikan sebagai sumber penghasilan yang memadai. Hidroponik merupakan cara bertanam tanpa media tanam tanah, seperti batu apung, kerikil, pasir, sabut kelapa, potongan kayu atau busa, namun menggunakan air bernutrisi. Tanah sebagai pendukung akar tanaman dan perantara larutan nutrisi dapat digantikan air bernutrisi dan oksigen.

Metode hidroponik juga merupakan metode yang dapat digunakan untuk meningkatkan pertumbuhan dan produksi tanaman karena dapat ditanam pada lahan yang sempit dan terkontrol. Ada berbagai macam metode hidroponik, diantaranya adalah: Static solution culture (kultur air statis); Continuous-flow solution culture, contoh: NFT (Nutrient Film Technique), DFT (Deep Flow Technique); Aeroponics; dan Biophonic. Dalam program KKN-PPM akan diberikan teknik continues flow solution culture kepada masyarakat di Muara Ancalong. 
Rudy Agung Nugroho, dkk. "Semampai” Sehat, Manajerial, Mandiri, Dan Pandai...

\section{Minat baca dengan perpustakaan}

Dalam program penumbuhan minat baca, tim pengabdian pada masyarakat KKN-PPM akan mengumpulkan buku-buku bacaan pendidikan dan pengetahuan dan mengumpulkannya di tempat yang sudah disediakan oleh yayasan ulin. Generasi anak SD dan SMP diberikan pengetahuan tentang manajemen penomoran perpustakaan dan pengelolaannya. Perpustakaan akan dibuka untuk umum, khususnya bagi generasi muda, sekolah dasar dan juga kalangan umum. Dalam program KKNPPM ini minat baca ditumbuhkan sejak dini. Para ahli berpendapat bahwa akan lebih menguntungkan bagi anak bila ia diberi pelajaran membaca pada usia sedini mungkin (as early as possible). Buku-buku juga akan diperbanyak dengan yang bergambar. Dengan buku bergambar yang baik, anak-anak akan terbantu dalam proses memahami dan memperkaya pengalaman dari cerita. Buku-buku bergambar dimaksudkan untuk mendorong ke arah apresiasi dan kecintaan terhadap buku. Selain ceritanya secara verbal harus menarik, buku harus mengandung gambar sehingga mempengaruhi minat siswa untuk membaca cerita (Santoso and Sos, 2011).

\section{HASIL DAN PEMBAHASAN}

Kegiatan KKN-PPM ini telah dilaksanakan di desa Kelinjau ulu dan ilir, Kutai Timur, Kalimantan Timur. Akses menuju desa Kelinjau ulu dan ilir dari kota Samarinda sekitar 6 jam perjalanan darat. Tempat pelaksanaan dan sasaran kegiatan ini adalah masyarakat di kedua desa tersebut.

\section{Persiapan kegiatan}

Kegiatan persiapan yaitu "brainstorming" KKN-PPM ini berlangsung bersama mitra yayasan ulin dan Yasiwa membahas rangkaian kegiatan bersama. Persiapan kegiatan KKN-PPM juga didiskusikan dengan perangkat desa yaitu Kepala desa Muara Ancalong untuk mempertajam programprogram tematik, maupun individu yang akan dijalankan selama 50 hari pelaksanaan.

\section{Pelaksanaan kegiatan}

Adapun dalam pelaksanaan, kegiatan-kegiatan yang telah dilakukan berhubungan dengan tema KKN PPM semampai adalah sebagai berikut:

\section{a. Hidup sehat dan manajemen sampah \\ Program hidup sehat dan} manajemen sampah dilaksanakan di kedua desa yaitu kelinjau ulu dan ilir. Program yang mendukung poin ini adalah: ecobrick, ecoenzyme, pembuatan dari bahan bekas (daur ulang) seperti hiasan bunga, kotak pensil, pot bunga, dan sahabat bumi serta biopori. Sahabat Bumi (Sami) merupakan suatu kegiatan yang bertujuan untuk memberikan pengertian kepada siswa tentang pentingnya menjaga ekosistem air, udara, maupun tanah. Siswa diajak mengetahui dampak- dampak yang terjadi apabila terjadi kerusakan lingkungan melalui percobaan Sederhana. Selain kegiatan tentang penunjang tema ini adalah tanaman obat keluarga juga disampaikan dalam kegiatan KKN PPM ini (Gambar 2). 


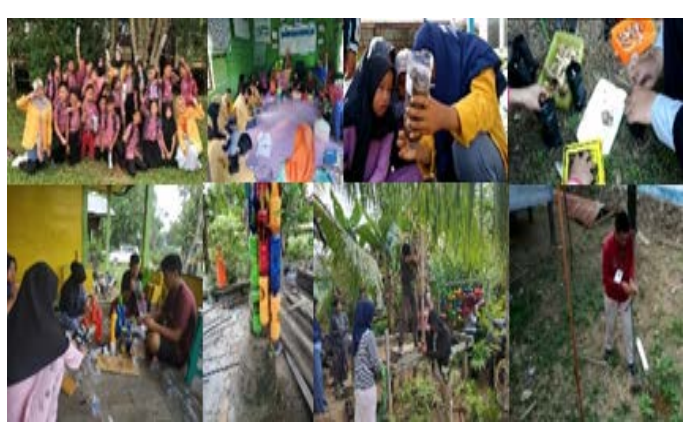

Gambar 2. Kegiatan yang terkait tema hidup sehat dan manajemen sampah

\section{b. Kemandirian pangan}

Hidroponik, pembuatan pupuk organik cair (POC), pengasapan ikan dengan bahan asap cair, pengolahan ikan menjadi produk pangan lain (Gambar 3). Dalam kegiatan ini melibatkan dasawisma, ibu-ibu PKK, kelompok nelayan dan warga dengan berbagai profesi. Kegiatan berlangsung interaktif dan disambut antusias oleh warga. Warga terlihat antusias dengan program yang ditawarkan tidak hanya pada saat program berjalan namun, setelah program, warga juga mencoba sendiri di tempat masing-masing.

\section{c. Pandai dengan perpustakaan dan minat baca}

Dalam program ini, kegiatan yang telah dijalankan adalah sebagai berikut: penyuluhan minat baca, bimbingan materi (BIMA), Rumah belajar mengajar di sekolah SD dan SMP setempat dan tangga baca (Gambar 4).
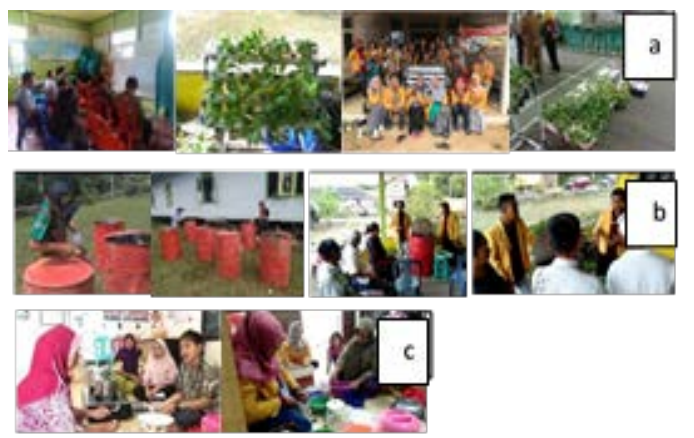

Gambar 3. Program tema Kemandirian pangan, a) hidroponik, termasuk pembuatan POC, b). pengasapan ikan c). Pengolahan produk ikan

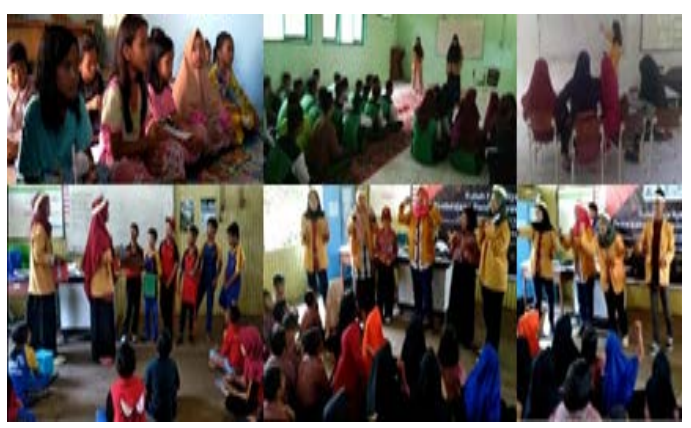

Gambar 4. Program tematik perpustakaan dan penumbuhan minat baca bagi anak SD dan SMP

\section{Monitoring dan Evaluasi}

Kegiatan KKN PPM ini juga mendapatkan monitoring dan Evaluasi dari dosen pendamping lapangan. Pada hari ke 30, dosen pendamping lapangan mengunjungi posko KKN dan lokasi kegiatan serta wawancara peserta KKN PPM. Tiap peserta dimonitoring dan Evaluasi tentang jalannya kegiatan, kendala yang dihadapi, dan penyelesaian kegiatan yang belum selesai. Kegiatan monitoring dan Evaluasi ini berlangsung selama dua hari di lokasi kegiatan (Gambar 5).

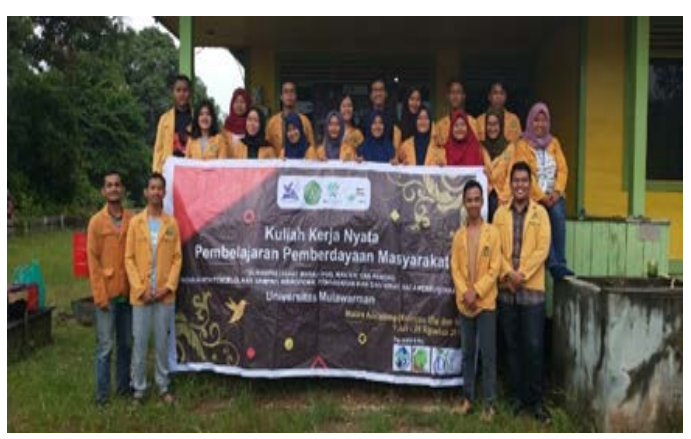

Gambar 5. Kegiatan monitoring dan Evaluasi oleh dosen pendamping lapangan (DPL) di posko KKN PPM

\section{Evaluasi dan kesan-kesan warga}

Menjelang Setiap kegiatan berakhir, peserta KKN PPM mewawancarai warga tentang kesan- 
Rudy Agung Nugroho, dkk. "Semampai” Sehat, Manajerial, Mandiri, Dan Pandai...

kesan setelah mengikuti programprogram yang telah dijalankan oleh peserta KKN PPM. Secara umum, warga antusias dalam mengikuti Setiap program dan merasakan manfaat serta mempunyai keinginan agar ilmu, praktek yang didapat dapat teruskan dan diperluas ke masyarakat yang lainnya.

\section{SIMPULAN}

Program kuliah kerja nyatapembelajaran dan pengabdian kepada masyarakat (KKN-PPM) telah dilaksanakan dengan baik dan melibatkan Pengabdi dan masyarakat desa Kelinjau ulu dan ilir, Muara Ancalong, Kutai Timur.

\section{UCAPAN TERIMA KASIH}

Tim Program KKN_PPM menyampaikan ucapan terima kasih atas hibah dana dari Kemenristekdikti dengan kontrak no: 226/UN17.41/KT/2019. Tim KKN PPM juga menyampaikan terima kasih kepada Fakultas MIPA, Universitas Mulawarman, Samarinda atas dukungan hingga terlaksananya masyarakat desa Kelinjau ulu dan ilir, Yayasan Khatulistiwa (Yasiwa), Yayasan Ilir, LP2M Universitas Mulawarman, dan semua civitas akademik Universitas Mulawarman atas dukungan dalam kegiatan ini.

\section{DAFTAR PUSTAKA}

Duta, D. K. (2015). pemerintah optimis produksi ikan tangkap RI 8 juta ton. Ekonomi. Retrieved from http://www.cnnindonesia.com/ ekonomi/20151221154919-9299639/2016-pemerintahoptimis-produksi-ikantangkap-ri-8-juta-ton/
Ghofar, M. (2016). Produksi perikanan Kaltim capai 154.439 ton. Retrieved from http://kaltim.antaranews.com/b erita/31700/produksiperikanan-kaltim-capai154439-ton

Ibrahim, N. M. (2014). Uji mutu ikan cakalang asap dari unit pengolahan ikan di Provinsi Gorontalo. Universitas Negeri Gorontalo.

Jeujanan, Samuel, Ijong, Frans G, Onibala, Hens, \& Mentang, Feny. (2015). Organoleptic quality and TPC of smoked skipjack tuna (Katsuwonus pelamis, L) in Jayapura, Papua. Aquatic science \& management (Jurnal Ilmu dan Manajemen Perairan), 3(1), 2631.

Nugroho, R. A, Santoso, Y. G. G., Nur, Firman, N, Hariani, N., \& Solikin, S.. (2016). A preliminary study on the biodiversity of fish in the Suhui River, Muara Ancalong, East Kutai, Indonesia. Aquaculture, Aquarium, Conservation \& LegislationInternational Journal of the Bioflux Society (AACL Bioflux), 9(2).

Prasetyo, D. Y. B., Darmanto, Y. S. \& Swastawati, F. (2015). Efek perbedaan suhu dan lama pengasapan terhadap kualitas ikan bandeng (Chanos chanos Forsk) cabut duri asap. Jurnal Aplikasi Teknologi Pangan, 4(3).

Royani, D. S., Marasabessy, I, Santoso, J., \& Nurimala, M.. (2014). Rekayasa alat pengasapan ikan tipe kabinet (Model oven). Jurnal aplikasi teknologi pangan, 4(2). 
Samuel, S., Martono, K. T., \& Susanti, M. T. (2015). Pemberdayaan masyarakat pesisir pantai di tambak lorok, Semarang, Jawa tengah. Kapal, 12(3), 145-150.

Santoso, H., \& Sos, S. (2011). Membangun minat baca anak usia dini melalui penyediaan buku bergambar. Jurnal. Malang: Universitas Negeri Malang.

Swastawati, F., Cahyono, B., \& Wijayanto, D. (2017).
Penerapan ipteks asap cair pada sentra pengasapan ikan di desa wonosari, kecamatan bonang, kabupaten demak. Info, 17(3), 143-165.

Widiyanto, W. N., Ibrahim, R., \& Anggo, A. D. (2015). The effect of processing temperature of simple steam jacket on the quality of white spotted whipray rays liver oil. Jurnal pengolahan hasil perikanan Indonesia, 18(1). 